Covered in: ERIH PLUS, CEEOL, Index Copernicus, CrossRef, CrossCheck, J-Gate, Google Scholar, Ideas RePeC, Econpapers, Socionet, KVK, WorldCat.

\section{Acting against Wish according to Will: John Locke's Ethics}

\section{Emilia TAJSIN1}

${ }^{1}$ Kazan State University of Power Engineering, Department of Philosophy, Krasnoselskaya 51, 420066, Kazan, Russia
Abstract: John Locke is best known for his theory of knowledge. However, this theory includes practical, social, moral issues, containing ethics and meta-ethics, the latter being interested in epistemological nature of moral judgments. In his most famous "Essay on Human Understanding" Locke analyzes the domain of morality, paying great attention to the dichotomy of pleasure and pain as the main axis round which this domain rotates. In this paper the accent is put on the "trichotomy" of Will, Desire, and Freedom, since people often act against their wishes but according to their own will. The conclusion is given, that control of one's passions is the true progress on the path of freedom. In order our mind was free to explore any subject and make a judgment, we must educate our passions. Trained morality turns the unpleasant or indifferent in a pleasant and welcome, if only people do everything in their power. And Philosophical law is the measure of virtue and vice.

Keywords: theory of knowledge; ethics; will; desire; freedom.

How to cite: Tajsin, E. (2019). Acting against Wish according to Will: John Locke's Ethics. Logos Universality Mentality Education Novelty: Philosopby \& Humanistic Sciences, 7(1), 78-90. doi: 10.18662/lumenphs/19 

When they do not know distant dreams, then they shall not escape nearest afflictions.

Lun $\mathrm{Yu}$

\section{Introduction}

For a contemporary philosopher it became a habit to regard the great English enlightener's theory as classics of materialistic, and nondialectical, gnoseology. By the end of the last century the nominal term "Lockean paradigm" even became current, say, in Russian philosophy, meaning obsolete theory of knowledge of "modernity" era. It was blamed of supporting the old-fashioned "correspondence" theory of truth and, mainly, of sensualism ("Perception is the first step and degree towards knowledge, and the inlet of all the materials of it") and nominalism ("genera" and "species" exist only for the purpose of signification) - which, by the way, are more than typical for the current trends in Anglo-Saxon philosophy. I am not about refuting the critique of the classical empiricist here; in this paper I'm aiming at the topic of modernity classics being more than contemporary in the realm of morality.

No gnoseology is purely theoretical, "just" theoretical; it is always closely connected not only with ontology (as an option, with natural philosophy), but also with ethics, being its alpha and omega, which is usually overlooked. In sum, gnoseology is built up to construct practical philosophy on its basis. Is not just a well-known position of Kant (or Epicurus); contemporary philosophers, too, take it up at least as a working hypothesis: "...Those who are interested in meta-ethics should adopt... that moral norms reduce to norms of reason and rationality". (Smith, 2013, p. 9). On its part, morality and ethics finding the basis in rationality and reason more often than not coincide with law and politics. We are not surprised when the best philosophers of the time of postmodernism, when treating about ethics, treat upon politics and law coincidentally: c.f., Jürgen Habermas (Habermas, 1992, 2001, 2003), Umberto Eco (Eco, 2000)... However, long before them - and before us - at the dawn of modern times, the similar views found its followers.

It is often forgotten that John Locke, not the French thinkers of the XVIII cent., was the first philosopher who opened the performance of Enlightenment, - and constructed a corresponding ethics, which was ahead of its time. For Locke it was immutable, that it is not only the natural sciences that intelligence constructs, but ethics, too - "the science of morality". 


\section{Locke's choice}

Consciousness of the first enlighteners was not alien to class prejudices. John Locke, an aristocrat, taught tribal nobility, his countrymen: "But this at least is worth the consideration of those who call themselves gentlemen, that, however they may think credit, respect, power, and authority, the concomitants of their birth and fortune, yet they will find all these still carried away from them by men of lower condition, who surpass them in knowledge". (Locke, 1985, item 6, p. $191^{1}$ ).

Knowledge is the first and best of human abilities, an indispensable companion and the condition of morality. Not only B. Spinoza thought so in the XVII cent. In the same way John Locke, a classical empiricist, thought arguing that in ethics the precise logical proof is quite possible (Locke, 1985, "Essay", Bk. III. Ch. XI, "Of the remedies of the Foregoing Imperfections and Abuses of Words", i.16, p. 575); in the same way great Aristotle figured; likewise, the first of the top ten philosophers of the world, Jürgen Habermas, affirms today. C.f.: "...The different approaches and interpretations simply reflect different interpretations of value. In a certain sense, all interpretations are rational". (Habermas, 2001, p. 51).

Actually, we all philosophers are asked the same two questions through thousands of years: 1) how this world is constructed and functioning, and 2) how do human beings have to act, what do people have to do, provided the world is so-and-so, - to be happy. John Locke was a new Epicurus arguing that we develop the science of the world, physics, in order to build morality on the basis of this knowledge, one that should be founded on a [purely epicurean] postulate: once every anxiety is removed, a moderate proportion of the benefit is quite capable to satisfy people. (Locke, 1985, "Essay", Bk. II. Ch. XXI, "Of Power", i.44, p. 311). (However, he treated "Epicureans" most critically, pointing out that the scientist will never be determined by the pursuit of good food, hot spices and fine wines. In fairness, it should be noted that Epicurus taught quite differently: his main concept was moderation).

Locke wrote the following about the essence and role of natural science and ethics in his famous "Essay":

"Physica... The knowledge of things, as they are in their own proper beings, their constitution, properties, and operations... The end of this is bare

\footnotetext{
1 All page numbers are given according to the Russian academic translation; viz. John Locke. Opyt o Chelovecheskom razumenii (An Essay Concerning Human Understanding), M. Mysl, 1985.
} 
speculative truth... Practica... The skill of right applying our own powers and actions, for the attainment of things good and useful. The most considerable under this head is ethics, which is the seeking out those rules and measures of human actions, which lead to happiness, and the means to practise them. The end of this is not bare speculation and the knowledge of truth; but right, and a conduct suitable to it". (Locke, 1985, "Essay", Bk. IV. Ch. XXI, "Of the division of the sciences", i. 2-3, p. 200)

Because the notion of material substance appears to Locke indistinct, and the method of its formation doubtful, hence comes the logical conclusion that, because of our ability not suitable for throwing light onto the inner nature of substances and the true essence of outer things ("We are fitted for moral science, but only for probable interpretations of external nature. From whence it is obvious to conclude that, since our faculties are not fitted to penetrate into the internal fabric and real essences of bodies", it seems - nay, it is necessary - to deal with those matters to which we are adapted. And this is ethics. (Locke, 1985, Bk. IV. Ch. XII, "Of the Improvement of our Knowledge", i.11, p. 125).

There are undoubtedly most important social phenomena as law, morality and religion, and in discussions of these things there lie the biggest hardships requiring all powers of our mind: "And in discourses of religion, law, and morality, as they are matters of the highest concernment, so there will be the greatest difficulty". (Locke, 1985, Bk. III. Ch. IX, "On the Imperfection of Words", i.22, p. 548).

\section{The domain of Locke's ethics}

The two great and principal capacities and operations of our mind are these two: thinking and volition, or willing. They are closely intervened. Locke examines carefully the range of ethical concepts, which he sees as simple ideas arousing both from sensation and reflexion, and the basic dichotomy appears as simple ideas of pleasure and pain, though "in truth they be only different constitutions of the mind, sometimes occasioned by disorder in the body, sometimes by thoughts of the mind", - Locke writes in the chapter "Of Modes of Pleasure and Pain" (Locke, 1985, Bk. II. Ch. XX, i. p. 283).

"These, like other simple ideas, cannot be described, nor their names defined", - he assumes, but "Things then are good or evil, only in reference to pleasure or pain". (Locke, 1985, "Essay", Book II. Ch. XIX, "Of the Modes of Thinking", i.2, p. 280). Pleasure and pain, enjoyment and anxiety, delight and trouble - "call it how you please" - is the axis around which our 
passions revolve. Even love and hatred are only the state of mind in relation to pleasure and pain in general. Everything that has the ability to cause pleasure we call good, and everything that can cause suffering - evil. If not Locke himself, then a contemporary author speaks about the degrees of states ("ideas") on this scale: "More goodness is better than less, some goodness is better than none, no goodness and no badness is better than some badness, and less badness is better than more". (Smith, 2013, pp. 1112).

Happiness is the greatest pleasure, to which we are capable, and misery - the highest suffering. (Locke, 1985, "Essay", Bk. II. Ch. XXI, i.42, p. 309). Epicurus taught the same! We were born to be happy, - contrary to what Kant affirmed with his "categorical imperative": we live to fulfill our obligations. Still these "imperatives" can be driven to balance, and later in this paper I'm going to show this.

By Locke, pleasure and pain, or anxiety, are not only bodily pain and pleasure, but all we experience from any pleasant or unpleasant sensation or reflection.

"That we call good, which is apt to cause or increase pleasure, or diminish pain in us; or else to procure or preserve us the possession of any other good or absence of any evil. And, on the contrary, we name that evil which is apt to produce or increase any pain, or diminish any pleasure in us: or else to procure us any evil, or deprive us of any good", -

Locke writes in the chapter "Of Modes of Pleasure and Pain" (Locke, 1985, "Essay”, Bk. II. Ch. XX, i.16, p. 283). In this he also resembles of Epicurus, as well as the teachings of the later Cyrenaica.

Basic ethical concepts, examined by Locke, are: desire, joy, love, hatred, sorrow, hope, fear, despair, anger, envy, happiness and misery, good, evil, freedom, will - and anxiety, Heidegger's "Sorge", which is the main, if not the only motif to work and action. Concerns have motive cause of action; anxiety is the "spring of action", as Locke puts it (Locke, 1985, Bk. II. Ch. XXI, i.34, p. 303). A major concern is inflicted by the lack of knowledge; for no man is so foolish who would negate that knowledge is a pleasure: "There is nobody, I think, so senseless as to deny that there is pleasure in knowledge" (Locke, 1985, Bk. II. Ch. XX, i.43, p. 310). So, the pursuit of knowledge is the pursuit of pleasure - and happiness. But is this pursuit voluntary - or involuntary? And what to say about the whole range of cases when a person is forcefully made to seek and gain knowledge, not really finding any pleasure in the process? 
An important question arises: how can a person act against his/her desires and wishes - according to his/her own will?

This is not the problem of pure abstract metaphysical interest; on the contrary, it is very practical. But to answer it, we have to make of use of a theory - Locke's theory of knowledge.

\section{Will, freedom, and happiness}

Since Parmenides, philosophers treat upon two main steps on the path of knowledge; feeling (sensation) and thinking (reason). Since the century of German classical dialectics, we are used to recognize human thinking tinted by sensation, and human perception controlled and transformed by reason; thus the metaphysical border among sense and thought is taken off which in German is called "Aufhebung”. Locke's theory of knowledge, standing historically in between, demonstrates its own instruments in dealing with these stages of the process, beginning from the fact that he, very materialistically, calls both images of perception and thinking - ideas. The more so: the power of perception of signs and ideas, their connexion or repugnancy, agreement or disagreement is that which he calls Understanding.

The most interesting thing for our arguments is Locke's contemplation on will, freedom and happiness (Locke, 1985, "Essay", Bk. II. Ch. XXI). Contrary to popular belief that he had been a metaphysical philosopher in his gnoseology, Locke appears in this reasoning as a true dialectician (if not a hermeneutist).

As it was already aforementioned, in humans, he confirms, there are two great powers: the mind [of which we think self-assuredly, we understand what it is-E.T.], - and the will which is an act of the mind directing its thought to the production of any action, and thereby exerting its power to produce it.

“...This power which the mind has thus to order the consideration of any idea, or the forbearing to consider it; or to prefer the motion of any part of the body to its rest, and vice versa, in any particular instance, is that which we call the Will”. (Locke, 1985, "Essay”, Bk. II. Ch. XXI, i.5, p. 287)

So, Locke seems to determine will as the moving power of action or a commander to rest; and the command itself is in power of mind, or thinking.

Here come some additional important definitions: 
“... The actual exercise of that power <will>, by directing any particular action, or its forbearance, is that which we call volition or willing. The forbearance of that action, consequent to such order or command of the mind, is called voluntary. And whatsoever action is performed without such a thought of the mind, is called involuntary". (Locke, 1985, "Essay", Bk. II. Ch. XXI, i.5, p. 287)

Also, he views anxiety as a feeling experienced by a person in the absence of things, which are in possession, or scope, of the idea of pleasure; it is considered the chief, if not the only spur to human industry and action: "The uneasiness a man finds in himself upon the absence of anything whose present enjoyment carries the idea of delight with it, is that we call desire; which is greater or less, as that uneasiness is more or less vehement". (Locke, 1985, "Essay”, Bk. II. Ch. XX, i.6, p.282). If a person feels easy and content without such a thing, it is no more but a bare velleity, some faint wish, the lowest degree of desire, Locke says.

Very well. Is anxiety a wish - or will, then? Or both? Since desires, it is obvious, are capable of playing a motivational role (Smith, 2013, p. 24)? The more so, both are intentional, aiming at the concrete "telos" of a certain object wanted; and, as all "goods and bads" are equally egocentric (quoted from: Smith, 2013, p. 2), both kinds of intentional anxieties are equal in this very important respect.

And here a problem arises, if not a contradiction.

First, wish and will should "not be confounded". The first is in the rank of psychology observing morals, the second is studied by ethics, the science of morality. Will belongs to the domain of normative, i.e., rational and reasonable. Wish dwells in emotional and sensational sphere and won't transfer into will until the "significational lift" transfiguring perceptions into wording and propositions (Tajsina, 2014, p. 139, 169), raises desire to the instrumental level of means-goal consideration. Locke, too, spoke of such "vertical" movement in the mind affirming that desire of great good, apprehended and acknowledged, can raise proportionally thus starting the will. (Locke, 1985, Bk. II, Ch. XXI, i.35, p. 303).

It is impossible [or rather forbidden] to confuse the desire and volition on one more ground. Wish and will may drive us to the opposite directions; and one of the most intriguing ethical problems is acting against one's desire - but according to one's will:

“...The will is perfectly distinguished from desire; which, in the very same action, may have a quite contrary tendency from that which our will sets us upon. A man, whom I cannot deny, may oblige me to use persuasions to 
another, which, at the same time I am speaking, I may wish may not prevail on him. In this case, it is plain the will and desire run counter. I will the action; that tends one way, whilst my desire tends another, and that the direct contrary way". (Locke, 1985, Bk. II. Ch. XXI, i.30, p. 300, 301)

BUT:

"I have above endeavoured to express the act of volition, by choosing, preferring, and the like terms, that signify desire as well as volition, for want of other words to mark that act of the mind whose proper name is willing or volition...” (Locke, 1985, Bk. II. Ch. XXI, i.30, p. 300, 301)

So - Anxiety and wish are determined by instruments of ordering, directing, choice and preference? And so is will? What, then, is the difference between them, aiming intentionally at the object of wishing, designed and driven by the same powers, working with the same tools to cause effect? And it is worth mentioning that Locke, though preferring the word "preference", warns that it is not absolutely fit to describe volition: "For example, preferring, which seems perhaps best to express the act of volition, does it not precisely. For though a man would prefer flying to walking, yet who can say he ever wills it?" (Locke, 1985, i. 15).

Further on: what is freedom?

"Is it worth the name of freedom to be at liberty to play the fool, and draw shame and misery upon a man's self? If to break loose from the conduct of reason, and to want that restraint of examination and judgment which keeps us from choosing or doing the worse, be liberty, true liberty, madmen and fools are the only freemen...". (Locke, 1985, Bk. II. Ch. XXI, i.51, p. 316)

Freedom involves both the mind and the will. And here we come to more so-called "circles".

The mind is induced by anxiety. The will is determined by the mind (Locke, 1985, Bk. II. Ch. XXI, i.28).

Without freedom, thinking and understanding would have no purpose: and without understanding, freedom (if it could exist at all) would signify nothing. (Locke, 1985, Bk. II. Ch. XXI, i.71). Or, to put it as a quotation, there can be no freedom where there is no thinking, or desire, or will: "... liberty cannot be where there is no thought, no volition, no will..." (Locke, 1985, Bk. II, Ch. XXI, i.8, p. 289).

Counter to that, there may exist such situations, where thought is there, and will, and volition, but still no freedom; "Wherever doing or not doing will not equally follow upon the preference of $<$ man's $>$ mind 
directing it, there he is not free, though perhaps the action may be voluntary". (Locke, 1985, Bk. II, Ch. XXI, i.8, p. 289).

Locke presumes that inspiration, necessary push, and unanimous action can bring freedom, though.

And then a bit down the page Locke declares that freedom cannot be not applied to volition as its attribute: "Liberty belongs not to the will". All discourse on "free will" is vague and absent-minded. Freedom is not inherent, and it will be approved in further items of the same chapter. "Whether man's will be free or no... is as insignificant... as to ask whether his sleep be swift, or his virtue square: liberty being as little applicable to the will, as swiftness of motion is to sleep, or squareness to virtue". (Locke, 1985, Bk. II, Ch. XXI, i.14, p. 292).

For Locke, freedom cannot be either state, or attribute, or modification of will.

Freedom is power.

The more so: will cannot be either state, or attribute, or modification (of mind).

"Will is also but a power"; the faculty to act, "the power of the mind to determine its thought, to the producing, continuing, or stopping any action, as far as it depends on us". (Locke, 1985, Bk. II, Ch. XXI, i.15, p.292).

These two powers, or "intentionalities", coincide in action.

"Liberty is freedom to execute what is willed. ...A man is not at liberty to will, or not to will, anything in his power that he once considers of: liberty consisting in a power to act or to forbear acting, and in that only. For a man that sits still is said yet to be at liberty; because he can walk if he wills it. A man that walks is at liberty also, not because he walks or moves; but because he can stand still if he wills it. But if a man sitting still has not a power to remove himself, he is not at liberty; so likewise a man falling down a precipice, though in motion, is not at liberty, because he cannot stop that motion if he would". (Locke, 1985, Bk. II, Ch. XXI, i.24, p. 287)

Freedom is not arbitrary, or random, or wanton. It is not a casual or accidental chance.

The arbitrariness of the opposite is involuntary, but not necessary: "Voluntary, then, is not opposed to necessary, but to involuntary. For a man may prefer what he can do, to what he cannot do; the state he is in, to its absence or change; though necessity has made it in itself unalterable". (Locke, 1985, Bk. II, Ch. XXI, i.11, p. 290). 
Freedom is not a necessity, either. When there is absolutely no thought or power to act or to restrain from action in accordance with our thought (plan, program), there we find the need, or necessity. Now, if we are capable of volition, it is called coercion; when some interference opposes volition, it is called deterrence. Locke put it in the following wording:

"Wherever thought is wholly wanting, or the power to act or forbear according to the direction of thought, there necessity takes place. This, in an agent capable of volition, when the beginning or continuation of any action is contrary to that preference of his mind, is called compulsion; when the hindering or stopping any action is contrary to his volition, it is called restraint. Agents that have no thought, no volition at all, are in everything necessary agents". (Locke, 1985, Bk. II, Ch. XXI, i.13, p. 291)

On the other hand, the need to achieve true happiness is the basis of all freedom (the latter, as we remember, cannot exist apart of contemplation). And the removal of uneasiness is the first step to happiness.

Everyone is constantly striving to such happiness that can meet him at the moment and in accordance with his existing ideas. Each wants what is part of the happiness and other things, recognized as good. Unfortunately, the vast majority of people is guided mainly by the laws of the hostel, to maintain its good name in the eyes of society, paying little attention to the highest laws of spirituality dwelling in estimative, evaluative propositions or the demands of authorities pronouncing deontological normative judgments.

But what is the "true happiness" that all men desire?

"Past doubt", everyone and everybody pursues such goal as true happiness: but when there is no trouble or pain, people are usually glad with any pleasure "at hand", not the remote hypothetic or feasible happiness. Also, we all are apt to cling to some habit or custom that we once found likeable. Satisfied with those, and thus being happy, we feel at ease with our lives, and our will sleeps, unlikely to push us to any action in pursuit of any other good - until some new wish inspired by significant or insignificant object or thought, disturbs the already-got happiness, and this new anxiety, making us uneasy and anxious once again, stirs the will. And not the greatest positive remote good determines the will, "but present uneasiness alone".

Obviously the greater good - like building an enlightened and just society or saving one's soul - is not always turning on human desires, while the slightest trouble bothers people and makes them work to get rid of it. The prevalence of some present pleasure or present pain is supported by human feeble nature, most strongly moved by passions to what is present. Not higher positive benefit, alas, determines the will and concern, says 
Locke. In most cases, as long as a person is content with the conveniences of life, and finds no perturbance in it, the will never is determined to any action that shall change these conditions. But when uneasiness comes, Will begins to stimulate Action.

“...Thus, how much soever men are in earnest and constant in pursuit of happiness, yet they may have a clear view of good, great and confessed good, without being concerned for it, or moved by it, if they think they can make up their happiness without it. Though as to pain, that they are always concerned for; they can feel no uneasiness without being moved. And therefore, being uneasy in the want of whatever is judged necessary to their happiness, as soon as any good appears to make a part of their portion of happiness, they begin to desire it". (Locke, 1985, Bk. II, Ch. XXI, i.44, p. $311)$.

Even the highest positive benefit of a person may be known by people - but not wanted, we can look at it without desire, pass them and be happy without them...

There is another obstacle to proper behaviour. A person might be of strong character and trained logic; he or she might well be following the path of duty - and good. Although these are very different types of normatives in ethics, deontic and evaluative, for now it is not so important as the problem of "precipitant mind": we are inclined to use our freedom to act more swiftly than we should, losing the opportunity to brood over the consequences of this action. Locke even views it as sort of inadvertency of human consciousness: "...Precipitancy causes as wrong a judgment as if it were a perfect ignorance". (Locke, 1985, Bk. II, Ch. XXI, i.69, p. 330). Sure, freedom, or not freedom, belongs to the one who has or has not a power to act. But untimely speed of rushing to practice, especially following some object of immediate desire, should be checked and well controlled.

Won't it be the loss of liberty? What corollaries and solutions does a noble Illuminator offer?

The explanations are as follows.

Imagine a man who sees clearly that something is very useful or very harmful, having no ability to move even one step towards or from it; what is the value of such seeing? Imagine a man who is freely rambling in perfect darkness, "what is his liberty better than if he were driven up and down as a bubble by the force of the wind?" (Locke, 1985, Bk. II, Ch. XXI, i.69, p. 330). 


\section{Conclusion}

There seems to exist a direct current of consciousness; wish stirred up by a certain relevant object sensed as valuable, lift of contemplation bringing desire to mind, mind that induces will, and freedom, which power at use has no better application than to provide an agent time to think. This curvilinear process, or rather a legion of orbits, transfigures a line and plane - to sphere of understanding and knowledge.

Philosophical law is the measure of virtue and vice. (Locke, 1985, "Essay", Bk. II, Ch. XXVIII, "Of other relations", i.10, p. 406). Moral life needs education and training. Philosophical science, ethics, states that it is wrong to think that people cannot turn that into action, which is unpleasant or indifferent, changing it in a "pleasant and welcome", if only they would do everything in their power. Due consideration will do so in some cases, and practice, diligence and habit - in most cases.

"Whether it be in a man's power to change the pleasantness and unpleasantness that accompanies any sort of action? And as to that, it is plain, in many cases he can. ...The relish of the mind is as various as that of the body, and like that too may be altered; and it is a mistake to think that men cannot change the displeasingness or indifferency that is in actions into pleasure and desire, if they will do but what is in their power. A due consideration will do it in some cases; and practice, application, and custom in most. (Locke, 1985, Bk. II, Ch. XXI, i.71, p. 332).

Control of one's passions is the true progress on the path of freedom. Our understanding and reason is the best instrument "to search and see, and then judge thereupon". In order our mind was free to explore and impartially consider and make a judgment, we must educate our passions... (Locke, 1985, Bk. II, Ch. XXI, i.53, p. 318). In what ways and in what direction? Are we free to wish or not to wish? Are we free to will or not to will?

Locke answers, that, in most cases, a man is not at liberty to forbear the act of volition, that is, the exertion of will, by which the action is performed or cancelled inevitably. "Liberty, it is plain, consists in a power to do, or not to do; to do, or forbear doing, as we will". But what is most important - this power provides the capacity to suspend volition and to give a thorough contemplation to the object of desire. Mind is responsible for our ill choice, not desire. And there is only one situation in which a person is free in volition; and it is the choice of a distant good as the goal that is due to pursue. 
"But yet there is a case wherein a man is at liberty in respect of willing; and that is the choosing of a remote good as an end to be pursued. Here a man may suspend the act of his choice from being determined for or against the thing proposed, till he has examined whether it be really of a nature, in itself and consequences, to make him happy or not. For, when he has once chosen it, and thereby it is become a part of his happiness, it raises desire, and that proportionably gives him uneasiness; which determines his will, and sets him at work in pursuit of his choice on all occasions that offer". (Locke, 1985, Bk. II, Ch. XXI, i.57, p. 320).

In conclusion, it is very important to remember the following warning and to consider the best advice made by Locke.

To venture a greater good leaving aside a less valuable goal, it would be very wrong and irrational to begin acting upon unknown circumstances, random choice, and uncertain guesses. This is not displaying the power of will bringing to life the freedom of action. This is not yet liberty to follow true happiness. NOT before a due examination was made, considering the weightiness of the matter; not before the concernment of not to make a mistake brought the mind to draw the right vector of movement - thus combining the due, the proper, the right and the good.

\section{References}

Eco, U. (2000). P'at' esse na temy etiki [Five essays on ethics issues], (E.

Kostyukovich, Trans.). Sainkt Petersburg: Publishing house "Symposium".

Habermas, J. (1992). Demokratia, razum, moralnost' [Democracy, reason, morality]. Moscow: Nauka Publishing.

Habermas, J. (2001). Moral'noye soznaniye I kommunikativnoye deistviye [Moral consciousness and communicative action] (D.V. Sklyadnev, Trans., B.V. Markov, Afterword). Sainkt Petersburg: Nauka Publishing.

Habermas, J. (2003). Filosofskiy diskurs moderniti [Philosophical discourse of Modernity] (Mikhail Belyaev, et al., Trans.). Moscow: Ves' mir (World Publishing House).

Locke, J. (1985). Opyt o Chelovecheskom razumenii [An Essay Concerning Human Understanding], Works, in 3 v. V. I, II, (A.N. Savin, Trans). Moscow: Mysl Publishing.

Tajsin, E. (2014). Filosofskiye Voprosy Semiotiki [Philosophical problems of semiotics]. Sainkt Petersburg: Aletheia.

Smith, M. (2013). Meta-ethics. In F. Jackson, M. Smith (eds.), The Oxford Handbook of Contemporary Philosophy. UK: Oxford University Press. 